\title{
Women Equity Strive in Society Depicted through Animation Film Characters
}

\author{
Carlo Yannick Leon \\ Department of Literature Studies \\ University of Cape Town \\ South Africa \\ carlo.leon@gmail.com \\ Emilia N. Schmidt \\ Psychology Department \\ IU Internationale Hochschule GmbH Erfurt \\ Germany
}

Citation: Leon, C. Y. \& Schmidt, E. N. (2021). Women equity strive in society depicted through animation film characters. Notion: Journal of Linguistics, Literature, and Culture, Vol 3(2), p. 112-125. http://doi.org/10.12928/notion.v3i2.4818

\section{Article Info}

Article History

- Article Received

September $6^{\text {th }}, 2021$

- Article Accepted

November $18^{\text {th }}, 2021$

\section{Keywords}

Female representation

Second-Wave feminism

Disney Renaissance

Gender equity

Film characters

\section{ABSTRACT}

The purpose of this research is to identify the female representation depicted in the Disney Renaissance and to investigate why Disney characters struggle to claim their equity as women in their society. The research methods used in this study are classified as qualitative and descriptive. The documentation method and taking notes techniques are used to collect data. The research also employs two method concepts to analyze the collected data, including a gender equity approach analysis and Simone de Beauvoir's second-wave feminism theory. The data consists of linguistic units from various Disney Renaissance stories. The writer discovered three parts in the description of female representations based on data analysis of the female representations depicted in Disney Renaissance: rebel, wise, and adventurous women; confident, intelligent, and repellent of domestication women; and masculine, loyal, and ambitious women. Furthermore, data analysis of Disney characters' struggles in claiming their equality as women in their society reveals that they outperform patriarchal expectations, reject domestication, and practice emancipation by appropriating masculine attributes and roles. 


\section{Leon, Carlo Yannick \& Schmidt, Emilia N. \\ Women Equity Strive in Society Depicted through Animation Film Characters}

\section{INTRODUCTION}

Literature is written communication whether, in the form of poetry, drama, or fiction, and it always communicates human experience and uses narrative devices[1]. Film and literature are two different things with the same goal of creating the greatness of human imagination and understanding. Both film and literature work together to promote the progress of human civilization. Both are complementary. One cannot replace the other, like letters and sounds in human communication. Film and literature inspire each other and sustain the human mind through actions, pictures, words, and replicating human life.

Various popular films adapted from stories in literary works such as folklore, short stories, and novels have their impressions on the audience and connoisseurs. This is seen in the production of films that are well known for their quality. Walt Disney's cooperation has used mythology, historical characters, fairy tales, and fables as the foundation for some fantastic animated films, which are very popular with many people, especially children. Thus, children often use Disney stories as examples in various aspects of life[2]. Walt Disney's films based on children's literature have gained him more recognition than any of his other endeavors[2].

Disney stories have become part of a show culture that has evolved into reproducing gender roles by both children and adults[3]. Moreover, these stories present powerful and sustained messages about gender and social relations. Gender roles are influenced by the media, family, environment, and society in socializing and forming relationships [4].

Walt Disney Corporation has a very long role in female film production, helping to shape the ideals of femininity for millions of little girls both in America and around the world. With the development of literature, the first Disney princess drew on associations of traditional femininity, indicating the widespread encouragement of these traits within 1930's American culture.

Disney strives to maintain the traditional ideals of femininity. However, the critical and popular failure of the work that makes the story in the movie shows that both story readers and film viewers find that the gender roles of Disney princesses are less assertive and less desirable. Disney has been battling with the public and their audience for many years, being accused of portraying their characters, specifically females, in stereotypical ways. The massive part of society that can influence the audience by comparing themselves to others is gender roles and their connotations [3].

Since Walt Disney's death, Disney has struggled through the entire length of the late 1980s[5]. Disney released the story based on an original tale created by the Grimm Brothers in their first full-length animated film in 1937, Snow White and the Seven Dwarfs but changed to create more entertainment for the generation that needs it[6].

Disney created a story of romance with cheerful music and a happy ending that took away the fear, violence, and unpleasant realities[3]. Disney's trend starts from a domestic woman who becomes a damsel-in-distress relying on a prince to come and save the life of a young and kind princess that portrays society's point of view of what is expected of women. Their gender roles are in the character of Snow White.

Therefore, Disney released a new Disney woman, "New Wave," who turned the female character into a kind of hero, with a voice and a desire for adventure: the heroine[7]. This new approach ushered in two decades of enterprising heroines, with progressive qualities and characters fully compatible with gender roles that are increasingly acceptable in societies where women have the same work as men[7].

Representations of women in Disney films are due partly to the fact that Walt Disney's personal feelings about family life shaped the Disney Company, and partly to the fact that his attitudes mirrored the patriarchal cultural beliefs of the 1940s about what roles women should play in society[3].

In this description above, the female representation in Disney will be fascinating to discuss. Most of the significant battles of the women's rights movement had been won and could be seen through women being accepted into college, women in the workplace, and access to things like birth control and abortion were in the 1980s. Even though equality is not entirely as desired, women continue to step up for 
their equal rights. From 1989 to 1999, Disney reclaimed their authority in the animation industry, and after several years of struggle, it later released The Disney Renaissance or Disney Golden Era[5].

The Disney Renaissance, as already mentioned, was one of the most successful eras of Disney animation[8]. Although the animation process generally became more expensive, films in the Disney Renaissance era had more profits than ever before. Furthermore, what marked the beginning of the period generally known as the Disney Renaissance was The Little Mermaid (1989) and during this era began to feature many non-Western characters or settings [8], such as Beauty and the Beast in 1991, Aladdin in 1992, Pocahontas in 1995 and Mulan 1998. With the cultural changes in America, Disney also started making changes in their princess movies. The pattern that arises in this Disney phase is that the main female protagonist seeks to be released from her societal bonds and expectations[9].

The princesses in this era are seen as rebellious, adventurous, and ambitious as they seek their freedom and roles. However, they can still feel happy at the ending of the story[10]. The second wave of the feminist movement challenged the social views of gender roles, especially women, and created the opportunity for change in the late 1960s until the early 1970s[9]. In the 1960s, women expended the courage and determination to seek equal opportunities, pay, advancements in the workplace and society (Walsh, 2010). Furthermore, they were seeking to change the way American society and culture characterized, spoke about, and respected women[10].

The writer presents this research using the secondwave feminism theory by Simone de Beauvoir. The writer uses Beauvoir's theory in her book, The Second Sex. She made clear that feminism in its second wave was about gender stereotypes. To help measure that the concept of the studies focuses on female representation, the writer uses a gender approach. The Gender equality approach on the conventions and hierarchies that determine women's and men's position in the family, community, and society, whereby men usually dominate women.
According to CIDA[12], gender equity requires equal enjoyment by women and men of socially valued goods, opportunities, resources, and rewards. Gender equity does not mean that women and men become the same, but their opportunities and life chances are equal. A heroine that stated them as "assertiveness," "independence," and desire to explore and delineates the progression of female characters toward embodying these previously offlimit characteristics[7].

This description elaborates how the female representation as the women to fight their equality to their desire for freedom, the equality, and those who have the heroine character defined by Stover above. The urgency of this study issues many cases related to how female representation in society fights gender equality. The occurrence of disparities in society with female characters, Disney stories tell the existence of these heroine characters within the scope of the Disney renaissance era, where many characters in Disney that somehow the audience makes Disney characters as role models, and characters in Disney Renaissance princess who have different personalities from previous princesses who are considered Damsels-in-distress and this study aims to inspire women to live with equal opportunities and challenge social views about gender roles. This study's benefits consist of theoretical and practical benefits, which are expected to be able to contribute to society in terms of gender awareness, including women.

Women were only considered homemakers and had to stay at home[13]. Since the early 1920s, the role of women began to be questioned, and their equality was fought for. They began to refuse the traditional standards, gender roles, and expectations[13]. At the end of the 1920s era, during the Great Depression, the women activist slowed down and almost vanished completely. The culture and society reinforced this stigma that the depression affected the role of women and a revival of the traditional view that women were meant to be in the home caring for their husbands and children and providing for their families.

The term feminism was coined in the year 1960. Generally, feminism is the women's movement to get their right to have the same degree and freedom in society, Feminism support women to be free and 


\section{Leon, Carlo Yannick \& Schmidt, Emilia N. \\ Women Equity Strive in Society Depicted through Animation Film Characters}

rejects all the discrimination that has been experienced by many women in the world[14]. Feminism gives opportunities for women to have the same equality as men and changes people's perspectives on women who are weak, helpless, and incompetent. Tong[14] states that feminism support women to grow and improve themselves to show their true colors.

Feminism has three waves. The first-wave has happened between the mid-19th century and the early 20 th century. The second-wave has surfaced between the 1960s and 1970s, refers to the women's liberation movement for equal legal and social rights. The extremism the second-wave feminist has exhibited to bring out their plan to achieve equality and freedom for women has made it infamous among its progeny. The third wave, beginning in the 1990s, refers to a continuation of, and a reaction to, second-wave feminism[15].

\section{Second-Wave Feminism}

Between the 1960s and 1980s, the second wave of feminism focused on equality and discrimination[15]. The end of the Second World War was a reaction to women returning to their roles as housewives and mothers[16]. The second-wave slogan, "The Personal is Political," identified women's cultural and political inequalities as an inseparable relationship and stimulated women to understand how their private lives reflect sexist power structures[15]. Second-wave feminism has also challenged women's domestic roles and the structural inequalities found in the workplace, reproductive rights, and access to public spaces[17].

In this wave, the movement where women created their own popular culture and spread through feminist films, music, books, and even restaurants[16], this movement was triggered by the publishing of Simone de Beauvoir's book, The Second Sex, first published in Paris in 1949[16]. In a book, Beauvoir started by describing a woman's life from her childhood years on. She looked at women first from a historical perspective. Then she pointed out that a woman's life is centered on marriage because even though a woman is not married, she can still control her life[18].
In the Second Wave, Beauvoir represents the section of the independent woman; as a complex, contradictory figure. According to Beck[19], Beauvoir's estimation of woman's potential for authentic freedom under the structures of patriarchal capitalism is bleak in that she does not envisage it possible for the woman to be accessible simply by occupying the spaces made available to them within those structures: the mother, the wife, the beauty, the obedient worker and so on. Beauvoir argues that an independent woman represents something other than "having it all." It requires the woman to take responsibility for what she already has in the place that she finds herself and take responsibility for a creative reworking of that situation[19].

With this description, to become an independent woman on Beauvoir's terms means undertaking an ongoing process towards freedom that has no predetermined destination insight. Beauvoir's statement is written in Feminism: A Very Short Introduction. The Image of an independent woman who; wants to be active, a taker and refuses the passivity man means to impose on her. The modern woman accepts masculine values; she prides herself on thinking, taking action, working, creating on the same terms as a man[20].

\section{METHODOLOGY}

This research uses qualitative and descriptive research methods with a literature review taken from selected Disney Renaissance Stories. Qualitative research refers to the what, how, when, and where of a thing, essence, and atmosphere. Thus, it refers to the meaning, concept, definitions, characteristics, metaphors, symbols, and descriptions[21]. This Qualitative data is obtained primarily from the selected Disney storybook, Disney Princess A Treasury of Enchanting Tales - Deluxe Treasury 196 Disney (Autumn, 2019), The Little Mermaid, Beauty and the Beast, Aladdin, Pocahontas, and Mulan. They were in the text, quotation, phrases, and clauses or sentences related to the points discussed in this research. The data were collected through documentation techniques. Documentation is the act of looking for data which concern with matters such as note, book, newspaper, magazine, transcript, and agenda[22]. Then, the second technique is taking notes[23] define 
it as paying attention to something and being sure to remember. After being collected, the data were proceeded and sorted into patterns, categories, or basic units so that results could be found and hypotheses could be formulated. In addition, the data were also analyzed by following the concept proposed by Sawyer[24] that used seven factors: archetype, culture, community, Family, self-autography, relationship, and episode.

\section{RESULT AND DISCUSSION}

According to Sawyer 2003, which defines her methodology using the concept to measure feminism in representing the Feminist Outlooks at Disney Princess with serpentine designed[24]. Sawyer used 7 factors; Archetype, Culture, Community, Family, Self-Autography, Relationship, and Episode. Those factors related to the feminist response through Disney. In this research analysis of the female representation in selected Disney renaissance stories, the writer describes the analysis based on the problem formulation using selected factors that are related to the concept, and divides them into three parts of the description of female representations; as a women who rebel, wise, and adventurous; Independent, smart, and repellent of domestication; and Masculine, loyal, and ambitious.

\section{Rebel, Wise and Adventurous}

\section{The Little Mermaid}

The Little Mermaid in 1989 marked the beginning of the period commonly known as the Disney Renaissance[8]. Ariel is the fourth Disney princess that captivated the world[25]. The Little Mermaid brought renewed interest in Disney films of the diversity of princesses and to the Disney Renaissance Princesses, which caught the attention of critics about its influence on young girls.

The little Mermaid has a female representation who rebel and adventurous, as seen from the environment and family where women are living in the royal family and controlled by them. When Ariel was doing her curious side exploring the human world, and her father (The King) found out about his daughter. This part of story reveals how the king took over the rules, and Princess Ariel prefers to choose what she likes, and ignores the rules that seem to limit her from doing what she likes;

The king confronted Ariel at her grotto. "I set certain rules and I expect those rules to be obeyed!" he cried. (Autumn, 2019, The Story of Ariel, p. 141)

Princess Ariel's story has a relationship against the audience, where to make young girls believe they are experiencing something new, to believe to anything they want to achieve when they grow up. This is evident in the opening sentence of the story. Though her curiosity and adventurous nature often get her in trouble, free-spirited Ariel is passionate and resolute in her belief that the decisions she makes are in her own best interest. (Autumn, 2019, The Story of Ariel, p. 135)

Princess Ariel has a fascination with the human world, as she prefers to get herself into something she likes. Princess Ariel was curious and had a sense for adventure. This part of the story reveals how Princess Ariel has a different character from other princesses in the palace, she prefers to know something new, and interesting. She seems adventurous with her curiosity;

Instead of performing to the palace, Ariel was busily exploring a sunken ship, she loved to collect treasures from the human world - something shiny caught her eye." have you ever seen something so wonderful in your entire life?”. (Autumn, 2019, The Story of Ariel, p. 136)

Next, Ariel was a different kind of princess all together. She was bold, and rebellious. This part of story, where she was willing and trying hard to sacrifice her voice and cultural identity to Ursula, the evil sea who wanted to rule the undersea kingdom, to get human feet in order to meet the prince. Suddenly, a green mist took away Ariel's voice, and Ursula locked it in a golden shell necklace... The next thing she knew, Ariel was on reading (Autumn, 2019, The Story of Ariel, p. 142-143)

\section{Pocahontas}

In 1995 Walt Disney Company release Disney's animated version of Pocahontas. Disney Pocahontas is depicted as a new type of female protagonist who is different from the previous women who live among men in society. Disney animated hero Pocahontas has 


\section{Leon, Carlo Yannick \& Schmidt, Emilia N. \\ Women Equity Strive in Society Depicted through Animation Film Characters}

been portrayed as a Disney heroine who differs from previous Disney characters to become an adventurous young woman who stands up for her beliefs. Pocahontas is a Native American princess, the audience in this Disney Story attracted a lot of attention to women. As reveals in Pocahontas's story, shows the power of a woman who rebel and love adventure.

In the story Pocahontas represents as a freespirited adventurer who will not allow others to define her, she has always believed in following her own path. In this part of story reveals while Pocahontas is out exploring, standing high oh her favorite cliff, thinking of her dream that means something. While she dives off the cliff, one of her best friends, Nakoma, asks her to come down and ask her father about it. On the other hand, when she told her father about her dream, her father surprised her by marrying a handsome and brave man named Kocoum, but Pocahontas could not see her dream marrying him;

"...Pocahontas told her father, chief Powhatan, about her dream. 'I think it's telling me something's about to happen, something exciting.' 'something exciting is about to happen. Kocoum has asked to seek your hand in marriage'. Pocahontas was surprised... T think my dream is pointing me down another path' She said softly." ... (Autumn, 2019, The Story of Pocahontas, p. 101)

Pocahontas represents a young woman who loves nature, spends her time exploring the land, she is curious, and wants to bring peace to her people. This part of the story reveals Pocahontas who is depicted in the story as she is close to nature, and is curious when she sees strange white clouds from above the treetops steaming in the distance;

"... Pocahontas climbed high into Grandmother Willow's branches. ... perched on a rock by the water's edge, watching the ship approach. Now she knew the strange clouds she had seen earlier were actually the sails of that unusual vessel." (Autumn, 2019, The Story of Pocahontas, p. 103)

Pocahontas reveals the representation of rebellion, meanwhile, to prove that she has a dream and desire, she wants to be the one who decides for herself. This part of the story reveals Pocahontas depicted as a wise woman, and she protects the one she loves, she asks her father to talk rather than fight, she takes a responsibility to take care of her people;

"...She begged her father to talk, rather than fight ... but if one of them did want to talk, you would listen to him, wouldn't you?' she asked. 'I'm trying to help my people,' Pocahontas replied, before slipping off into the woods." (Autumn, 2019, The Story of Pocahontas, p. 108109)

As she represented to save John Smith, and made her father and her people aware that what they did all come here with anger in their hearts. This part of the story reveals Pocahontas has spoken with wisdom beyond her and comes with courage and understanding, and stops her father from killing John Smith;

"... this is where the path of hatred has brought us, this is the path I choose Father. What will yours be? ... chief Powbatan spoke Pocahontas speaks with courage and understanding from this day forward, if there is to be more killing, it will not start with me. Release him'." (Autumn, 2019, The Story of Pocahontas, p. 112)

\section{Confident, Intelligent and Repellent of domestication}

Beauty and The Beast

Walt Disney Company made the film Beauty and the Beast In 1991 and Belle is the fifth protagonist and second princess of the Disney Renaissance era. Belle fascinated for her appearance and smart, but her intellects are ridiculed in the story for love of reading, confident, also show a need for protection[17]. In the story the Audience is young girls and the Disney aimed to be a wholesome family story and women are working and taking care of the family (Autumn, 2019).

Belle is one of the princesses who is repellent of domestication, all that didn't stop her from being wanted to live wider than the place she lived in, Belle loves freedom, and has a sign of Independent. This part of story found that Belle likes reading books, reveals the part where Belle stuck in a provincial life that has left her curious to learn more about the world and a desire for adventure.

She loves books and Always be found reading (Autumn, 2019, The Story of Belle, p. 151). 
... It's my favorite! far-off places, online sword fights, magic spells, a prince in disguise ... (Jeff Sheridan, 2010, p. 5)

Belle is a down-to-earth girl, she is not interested in the marriage that Gaston, the arrogant rich man who loves her, has to offer. In this part of the story Belle a bit of a feminist to boot, she refused when Gaston said that he wanted to marry her. This sense of powerful spirit for positions where Belle as a female representation who constrained by society through marriage pressure, she shows repellent of domestication and refute royal status, she has a desire to escape from that surroundings.

Though seen as different to other girls, this didn't stop Gaston, the handsome Idol of the village, wanting to have Belle as his wife. ... Belle didn't want to marry him. She found him boring and rude. She also disliked his attitude to her love of books. ... It's not right for a woman to read, he said. ... I'm very sorry, Gaston, I don't deserve you, she said sarcastically (Autumn, 2019, The Story of Belle, p. 151-154)

Belle in Beauty and the Beast wants a life of her own choice and acts for. Although motivated by freedom, Belle also defies her father's wishes and sacrifices her freedom for the release of her father from the Beast's castle. This Part in the story where she showed confident to save her father, without hesitation, and it's also revealed that she can live by her own choice.

"I've come for my father ... than take me instead", pleaded Belle. The Beast accepted her offer with one condition. She had to promise to stay forever. (Autumn, 2019, The Story of Belle, p. 155)

This part of the story, in the statement of one of the castle residents, Mrs. Potts, who knows Belle is confident and chooses the decision to stay at the castle to save her father.

"That was a brave thing you did," said Mrs. Potts, who knew Belle had chosen to stay in order to save her father. (Autumn, 2019, The Story of Belle, p. 156)

\section{Aladdin}

Aladdin is an animated film released by Walt Disney Pictures in 1992. Aladdin is the fourth film produced during the Disney Renaissance. The main protagonist of this story is Princess Jasmine, she is the first Princess of non-European descent, who introduced the Princesses to racial diversity. Princess Jasmine has female representation, it can be seen from the environment and family where women live in the royal family where everything is controlled by royal status, and marriage.

Princess Jasmine showed confident and repellent of domestication against her father when her father made a rule for her to get married. In this part of the story reveals where Princess Jasmine refuses to marry, and leaving the palace to avoid marriage, she seeks freedom from marriage outside the palace;

"... Jasmine decided she would rather leave her life as a princess than be forced to marry against her will. "I am sorry, Rajah ... I can't stay here and have my life lived for me...”(Autumn, 2019, The Story of Jasmine, p. 43)

The relationship with the female representation in Aladdin's story highlights Princess Jasmine, where she wants to fend for herself not to attribute royal status to marriage and to be equal. This part reveals Princess Jasmine is confident by stating even if she is forced to marry later, at least she can lead the kingdom;

"At least some good will come of my being forced to marry, ... when I am queen, I will have the power to get rid of you"

(Autumn, 2019, The Story of Jasmine, p. 50)

Princess Jasmine definitely possesses confident as shown in her resistance character at which point Aladdin returns to her in his magical disguise as Prince Ali. This part reveals when princess Jasmine rejects Aladdin disguising himself as Prince Ali, he wanted to marry her with so much quality. Princess Jasmine's main concern is deciding whom she will marry, not because of royal status, saying that she is not a prize to win.

"Jasmine who didn't recognise Aladdin, was far from impressed. She wasn't a prize to be won" (Autumn, 2019, The Story of Jasmine, p. 50)

Although in the end, Jasmine had little interest in Prince Ali (Aladdin), Princess Jasmine refused, because she stated that she was not a prize to be won. This part of the story reveals the moment where Jasmine feels that Prince Ali is arrogant and she refuses to have him appear from the balcony wanting to show her that he is not arrogant. 


\section{Leon, Carlo Yannick \& Schmidt, Emilia N. \\ Women Equity Strive in Society Depicted through Animation Film Characters}

"Wanting to show Jasmine he wasn't as arrogant as he had appeared, Aladdin still disguised as Prince Ali Ababwa, visited her that night. "Leave me alone" said Jasmine" (Autumn, 2019, The Story of Jasmine, p. 50)

\section{The little Mermaid}

Meanwhile, Ariel who represents women as rebels, she is also confident with her choices, even though she lost her voice, and the Prince did not realize that Ariel was the princess who had saved her, she did not stop and tried hard to convince the prince that it was her. In this part of the story where Princess Ariel is portrayed as a woman who never gives up and persistent, she achieves self-actualization with the destruction of the sea witch's golden shell necklace and the return of her voice, Ariel turns into herself again, the mermaids. Even so, at the end of the story the King who was finally able to see how much Princess Ariel loved Prince, he decided to turn her leg, so she could live on land;

Ariel had become a mermaid again and her soul belonged to the sea witch.... the king decided to turn ber fins back into legs once more, so she could live on land with her reading (Autumn, 2019, The Story of Ariel, p.147-148)

\section{Masculine, Loyal and Ambitious}

\section{Mulan}

In 1998, Disney Animated Company released a portrayal of Disney princess based on a true story and medieval Chinese legend, Mulan. The story of Mulan was the first Asian princess which was criticized for stereotyping. The story of Mulan portrays values about womanhood, such as; women are equal to men, women are different than men, and women should follow their hearts. The story is set within patriarchal societies and represents women to obey traditional roles, women are living in societies that deem a woman's outward appearance of utmost importance.

This part of the story reveals Mulan's beginnings represent herself to be loyal to her family preparing to meet the town matchmaker and striving to fulfil traditional roles in marriage which people believe would bring honor to her family;

"...Mulan was preparing to meet the town Matchmaker later that day she wrote on her arm so she would remember what to say; '... quiet and demure, graceful, polite...' a good match and a good marriage would bring honour to her family." (Autumn, 2019, The Story of Mulan, p. 23)

Since honor was such a large part of her culture, it all caused her to suffer from her inability to become a woman worthy of the family according to society. Mulan felt that she had not been able to fulfil family honoraria, because things didn't go well during the matchmaker. When the announcement that one man from every family must serve in the imperial army, but his father, Fa Zhou was not strong enough to survive another war.

This part of the story reveals an ambitious Mulan, Mulan makes a decision to go to war, changes her appearance into a man because only men can join the war, this part also reveals Mulan is loyal to her family, she longs to bring honor to her family, she is not afraid to take risks, because she's tough and strong to save her father in disguise;

“...Moving quietly, Mulan took Fa Zhou's conscription orders from his table, cut her hair short with her father's sword and dressed in his armour. ... Even though women were forbidden to be soldiers, she would join the army risking her own life to save her father's." (Autumn, 2019, The Story of Mulan, p. 26)"

In the story of the Disney Renaissance, the most apparent form of appropriating masculine attribute and roles is found in Mulan. Mulan represents like the previous female main characters, which experiences societal rejection. She was not considered worthy to marry in order to maintain the honor of her family. However, out of her deep love for her father and desperation for finding her true identity, she challenges all social boundaries. She was dressed as a man and joined the army in place of her father without her family knowing.

This part of the story reveals the story where Mulan initially disparaged when her true gender is revealed, but she represents her ambitious spirit, she proves to be a sturdy soldier and a trustworthy companion, she either not only saves a man's life, but she also saves the entire nation of China, she is primarily responsible for ending the war, her country eventually celebrates her;

"...The Emperor approached Mulan. T've heard a great deal about you' be said sternly. 'You stole your father's 
armour, impersonated a soldier, dishonoured the Chinese Army, destroyed my palace and ... save us all" then, to everyone's amazement, the Emperor bowed to Mulan." (Autumn, 2019, The Story of Mulan, p. 37)

The last story reveals where Mulan loyalty proves that bringing honor to the family is not just by marriage, as the Emperor said in the sentence that 'The flower that blooms in adversity is the most rare and beautiful of all' This sentence means that Mulan has faced all rejection that happened to her, describing Mulan as a flower which highlights that being different and facing hardships is acceptable;

"... The greatest gift and honour is having you for daughter' Fa Zhou said ... Mulan had become a hero and a leader, bringing honour to ber family in her own way. It was time to celebrate!" (Autumn, 2019, The Story of Mulan, p. 38)

\section{Pocahontas}

Pocahontas is seen as the first princess to make decisions filled with desires, thoughts, and feelings. As reveals in Pocahontas's story who rebel and adventurous, Pocahontas also shows the female representation who shows the power of a woman who has masculine and loyal to her people.

She decided not to go with the man she loved, but stayed for her Tribe, the stereotypical decision of life in her tribe with her family and people. This Story Reveals Pocahontas is as a loyal to protect the one she loves, protects the tribe, and takes responsibility for taking care of the tribe by taking the decision not to leave the Tribe.

"... She knew her path. She was needed here, to help forge the fragile bond between her people and the settlers who would be staying on through the cold winter to come." (Autumn, 2019, The Story of Pocahontas, p. 112)

Meanwhile, other stereotypical decision, she also performs the masculine action, this part of story reveals when she throws herself over John Smith to save him, she does not let her father's dominance interfere with her heart. She is definitely represented as the female protagonist, displaying strength, standing at the path she chooses, and spirit;

"... Suddenly, Pocahontas threw herself on top of smith. If you kill him, you'll have to kill me, too!' everyone stared in stunned silence. "look around you, ... this is where the path of hatred has brought us, ..." (Autumn, 2019, The Story of Pocahontas, p. 112)

Beauty and the Beast

Belle represents women as confident and smart. Furthermore, she also represents as a loyal daughter to take care of her father and saves him. This story reveals Belle who is loyal as an only daughter to save her father;

"Papa! She cried, rushing over him. "I've got to get you out of here!” (Autumn, 2019, The Story of Belle, p.154)

Furthermore, the story that revels Belle represents a loyal woman, where she returns for the Beast after the Beast gives Belle a chance to meet her father whom she saved from Gaston;

"You came back?" he said. Weakly. "of course, I came back." Belle replied (Autumn, 2019, The Story of Belle, p. 163).

\section{Disney Character's struggles in claiming their equality as a woman in their society}

With the theory description, the writer developed a data analysis regarding how Disney characters struggle in claiming their equality as a woman in their society using a Beauvoir statement written in the book Feminism: A Very Short Introduction by Walters[20]. With a description table for each story, which is divided into the analysis; character struggles, theory description, and supporting data that contains phrases, sentences, clarification.

Exceeding patriarchal expectations

In this section there are two character's struggles that are explained in the story; The Little Mermaid, and Pocahontas.

\begin{tabular}{lll}
\hline \multicolumn{1}{c}{$\begin{array}{c}\text { Character's } \\
\text { Strive }\end{array}$} & Description & \multicolumn{1}{c}{ Context } \\
\hline $\begin{array}{l}\text { Exceeding } \\
\text { patriarchal } \\
\text { expectations, }\end{array}$ & $\begin{array}{l}\text { "Wants to } \\
\text { be active, } \\
\text { a taker, she } \\
\text { breaks }\end{array}$ & $\begin{array}{l}\text { 1. } \\
\text { prides, } \\
\text { Thought her curiosity } \\
\text { and adventurous nature } \\
\text { get her in trouble, free- } \\
\text { spirited, Ariel is }\end{array}$ \\
$\begin{array}{l}\text { patriarchal } \\
\text { expectations, } \\
\text { and through } \\
\text { hard work } \\
\text { thinking }\end{array}$ & and taking & $\begin{array}{l}\text { Passionate and resolute in } \\
\text { her belief that the } \\
\text { decisions she makes are } \\
\text { in her own best interest. } \\
\text { (Autumn, P.135) }\end{array}$ \\
\hline
\end{tabular}




\begin{tabular}{|c|c|c|}
\hline $\begin{array}{l}\text { persistence } \\
\text { she achieves } \\
\text { self- } \\
\text { actualization. }\end{array}$ & 5. & 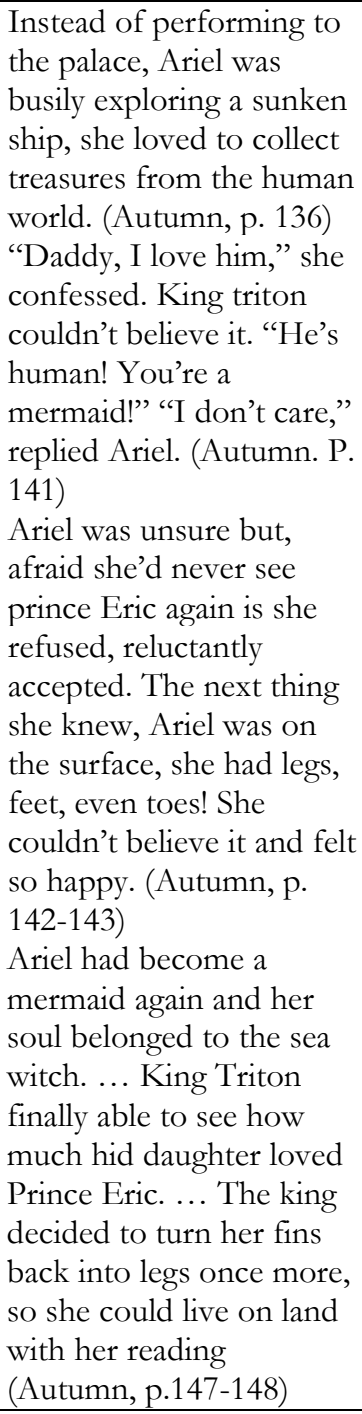 \\
\hline
\end{tabular}

Table 1. The Story of Ariel in The Little Mermaid, p. 135-148

\begin{tabular}{|c|c|c|}
\hline $\begin{array}{c}\text { Character's } \\
\text { Strive }\end{array}$ & Description & Context \\
\hline $\begin{array}{l}\text { Exceeding } \\
\text { patriarchal } \\
\text { expectations, } \\
\text { breaks } \\
\text { through } \\
\text { patriarchal } \\
\text { expectations, } \\
\text { through belief } \\
\text { and } \\
\text { persistence } \\
\text { she achieves } \\
\text { self- } \\
\text { actualization. }\end{array}$ & $\begin{array}{l}\text { "Wants to } \\
\text { be active, } \\
\text { a taker, and } \\
\text { refuses the } \\
\text { passivity } \\
\text { man means } \\
\text { to impose } \\
\text { on her. } \\
\text { She prides } \\
\text { herself on } \\
\text { thinking } \\
\text { and taking } \\
\text { action" }\end{array}$ & $\begin{array}{l}\text { 1. A free-spirited adventurer } \\
\text { who will not allow others } \\
\text { to define her, Pocahontas } \\
\text { has always believed in } \\
\text { following her own path. } \\
\text { (Autumn, p. 99) } \\
\text { 2. A young woman called } \\
\text { Pocahontas was out } \\
\text { exploring, ... standing } \\
\text { high on her favorite cliff, } \\
\text { she gazed out over the } \\
\text { lush green land. ... } \\
\text { "Thinking about my } \\
\text { dream,... I know it means } \\
\text { something. I just don't } \\
\text { know what." (Autumn, p. } \\
\text { 100-101) "something exciting is } \\
\text { about to happen." Her } \\
\text { father smiled. "Kocoum }\end{array}$ \\
\hline
\end{tabular}

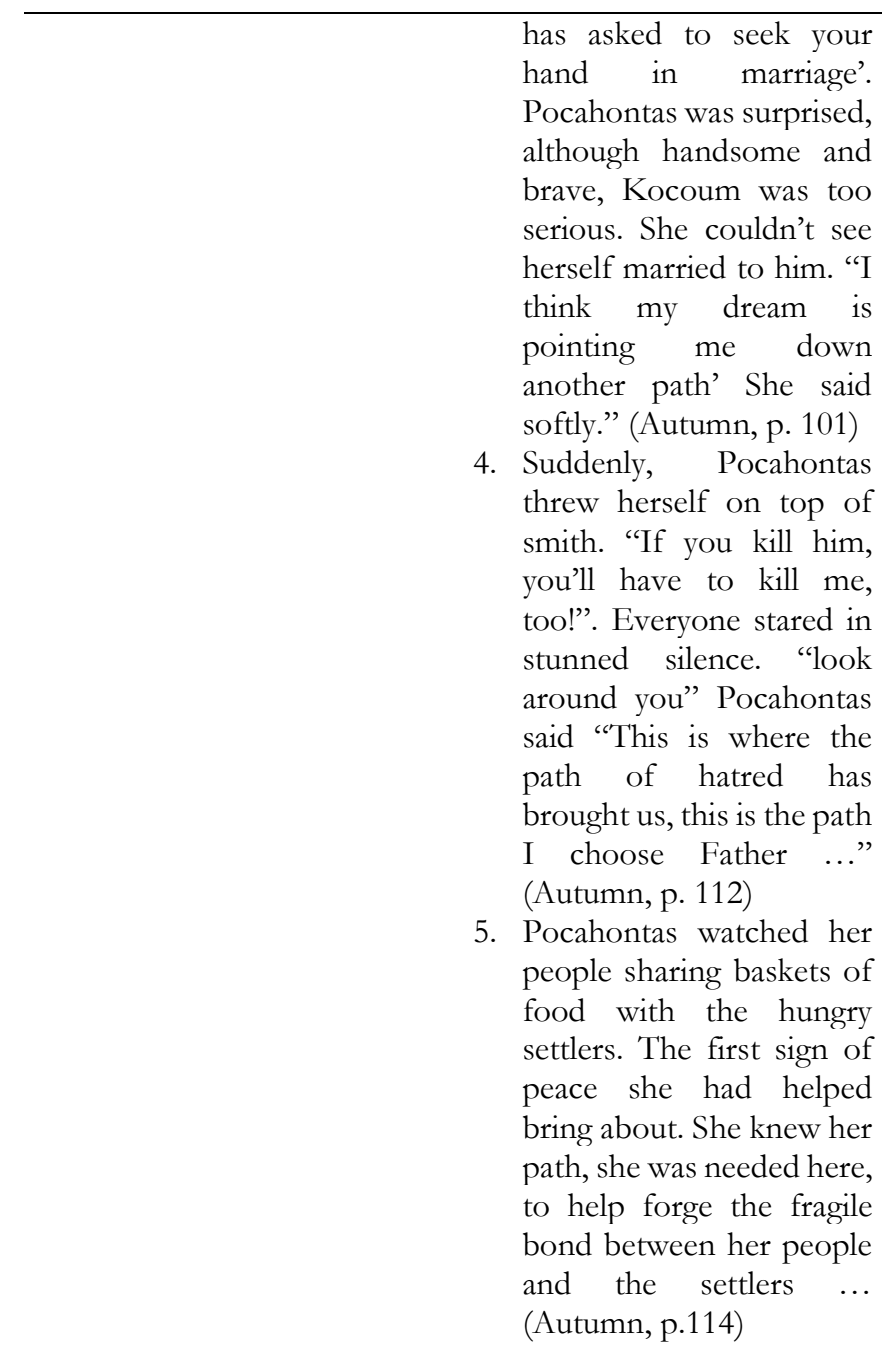

Table 2. Pocahontas, p. 99-114

Female exceed against patriarchal is depicted by the protagonist in the selected Disney Renaissance story, Disney heroines exceeding patriarchal expectations through independence and persistence. They actuate their dreams and breaks through patriarchal expectations, and through hard work and persistence, they achieve self-actualization. The finding analysis strongly conveys that young women should persist and move beyond those expectations. In this category, the data contained in the story of The Little Mermaid, and Pocahontas. Ariel is exceeding patriarchal expectation against her father to keep wanting to be Human, and to explore the realms beyond their kingdoms, she proudly taking action by making the decision in her own best interest outside the kingdom to begin her journey of selfactualization. Pocahontas also exceeds patriarchal expectations, she decides through hard work to 
achieve self-actualization, she prides herself on thinking and taking action to save John Smith and her people from the path of hatred that has brought them, and independently she defines her own path.

Rejecting domestication and applying the emancipation

In this section there are two character's struggles that are explained in the story; Beauty and The Beast, and Aladdin.

\begin{tabular}{|c|c|c|}
\hline $\begin{array}{c}\text { Character's } \\
\text { Strive }\end{array}$ & Description & Context \\
\hline $\begin{array}{l}\text { Rejecting } \\
\text { domestication } \\
\text { applying the } \\
\text { emancipation } \\
\text { from the role } \\
\text { of the } \\
\text { domesticated } \\
\text { woman }\end{array}$ & $\begin{array}{l}\text { "Wants to } \\
\text { be active, a } \\
\text { taker, and } \\
\text { refuses the } \\
\text { passivity } \\
\text { man means } \\
\text { to impose } \\
\text { on her. } \\
\text { She prides } \\
\text { herself on } \\
\text { thinking } \\
\text { and taking } \\
\text { action" }\end{array}$ & $\begin{array}{l}\text { 1. Belle is stuck in a } \\
\text { provincial life that has left } \\
\text { her curious to learn more } \\
\text { about the world... Belle is } \\
\text { brave enough to make her } \\
\text { own choices. (Autumn, } \\
\text { p.149) } \\
\text { 2. She loved books and } \\
\text { would always be found } \\
\text { reading. Though seen as } \\
\text { different to other girls, this } \\
\text { didn't stop Gaston, } \\
\text { wanting to have Belle as } \\
\text { his wife. ... Belle didn't } \\
\text { want to marry him. She } \\
\text { found him boring and } \\
\text { rude. (Autumn, p. 151) } \\
\text { 3. She also disliked his } \\
\text { attitude to her love of } \\
\text { books. "It's not right for a } \\
\text { woman to read," he said. } \\
\text {... Belle ignored Gaston } \\
\text { and went back home. } \\
\text { (Autumn. P. 151-152) } \\
\text { 4This is the day your } \\
\text { dreams come true" he said. } \\
\text { "Say you'll marry me". } \\
\text { "I'm very sorry, Gaston, } \\
\text { But I don't deserve you". } \\
\text { she said sarcastically, } \\
\text { before forcing him out the } \\
\text { house. (Autumn, p. 154) } \\
\text { "I've come for my father. } \\
\text {.. than take me instead", } \\
\text { pleaded Belle. The Beast } \\
\text { accepted her offer with } \\
\text { one condition. She had to } \\
\text { "Yomise to stay forever. (Autumn, p.155) }\end{array}$ \\
\hline
\end{tabular}

Table 3. The Story of Belle in Beauty and The Beast, p. 149-164

\begin{tabular}{|c|c|c|}
\hline $\begin{array}{c}\text { Character's } \\
\text { Strive }\end{array}$ & Description & Context \\
\hline $\begin{array}{l}\text { Rejecting } \\
\text { domestication } \\
\text { applying the } \\
\text { emancipation } \\
\text { from the role } \\
\text { of the } \\
\text { domesticated } \\
\text { woman }\end{array}$ & $\begin{array}{l}\text { "Wants to } \\
\text { be active, a } \\
\text { taker, and } \\
\text { refuses the } \\
\text { passivity } \\
\text { man means } \\
\text { to impose } \\
\text { on her. } \\
\text { She prides } \\
\text { herself on } \\
\text { thinking } \\
\text { and taking } \\
\text { action" }\end{array}$ & $\begin{array}{l}\text { 1. Princess jasmine goes on } \\
\text { an amazing journey of } \\
\text { discovery as she refused } \\
\text { to conform to society's } \\
\text { outdated ways. Through } \\
\text { her daring and open- } \\
\text { minded nature, Jasmine is } \\
\text { able to show those around } \\
\text { her that that who you are } \\
\text { within matters most of all. } \\
\text { (Autumn, p.39) } \\
\text { 2. Jasmine decided she } \\
\text { would rather leave her life } \\
\text { as a princess than be } \\
\text { forced to marry against } \\
\text { her will. "I am sorry, } \\
\text { Rajah ... I can't stay here } \\
\text { and have my life lived for } \\
\text { me... with her tiger's } \\
\text { help, the princess climbed } \\
\text { over the palace wall and } \\
\text { was gone. (Autumn, p. } 43 \text { ) } \\
\text { 3. Jasmine was angry with } \\
\text { Jaffar. She believed he had } \\
\text { god rid of Aladdin } \\
\text { forever. At least some } \\
\text { good will come of my } \\
\text { being forced to marry, ... } \\
\text { when I am queen, I will } \\
\text { have the power to get rid } \\
\text { of you. (Autumn, p. 50) } \\
\text { The sultan was delighted a } \\
\text { prince of such quality } \\
\text { wanted to marry his } \\
\text { daughter. Jasmine who } \\
\text { did not recognize } \\
\text { Aladdin, was so far from } \\
\text { impressed she wasn't a } \\
\text { (Autumn, p. } 51 \text { ) } \\
\text { 4rize won. }\end{array}$ \\
\hline
\end{tabular}

Table 4. The Story of Jasmine in Aladdin p. 39-56

The terms of domesticated women, Disney Heroine Rejecting domestication and applying the emancipation through independence and to emancipate themselves from their domesticated role in the society. In the selected Disney renaissance, the character's struggle in claiming their equality to get their self-actualization by not following traditional feminine. The finding analysis strongly conveys that women still can have the desire to begin the journey into the outside world and independently reject people domesticating them. In this category, the data contained in the story of Belle in Beauty and the Beast, and Jasmine in Aladdin. Belle is refuses to 
marry, refuses the passivity man means to impose on her and does not follow the traditional feminine, she prides to be free to choose who she deserves to marry and rejecting the role of a domesticated woman. Jasmine also prides herself on thinking and taking action, she wants to be active, seeking freedom from marriage and society's outdated ways, Jasmine also refuses the passivity man means to impose on her and defines her own path.

Appropriating masculine attributes and roles

In this section there is one character's struggles that is explained in the story; Mulan.

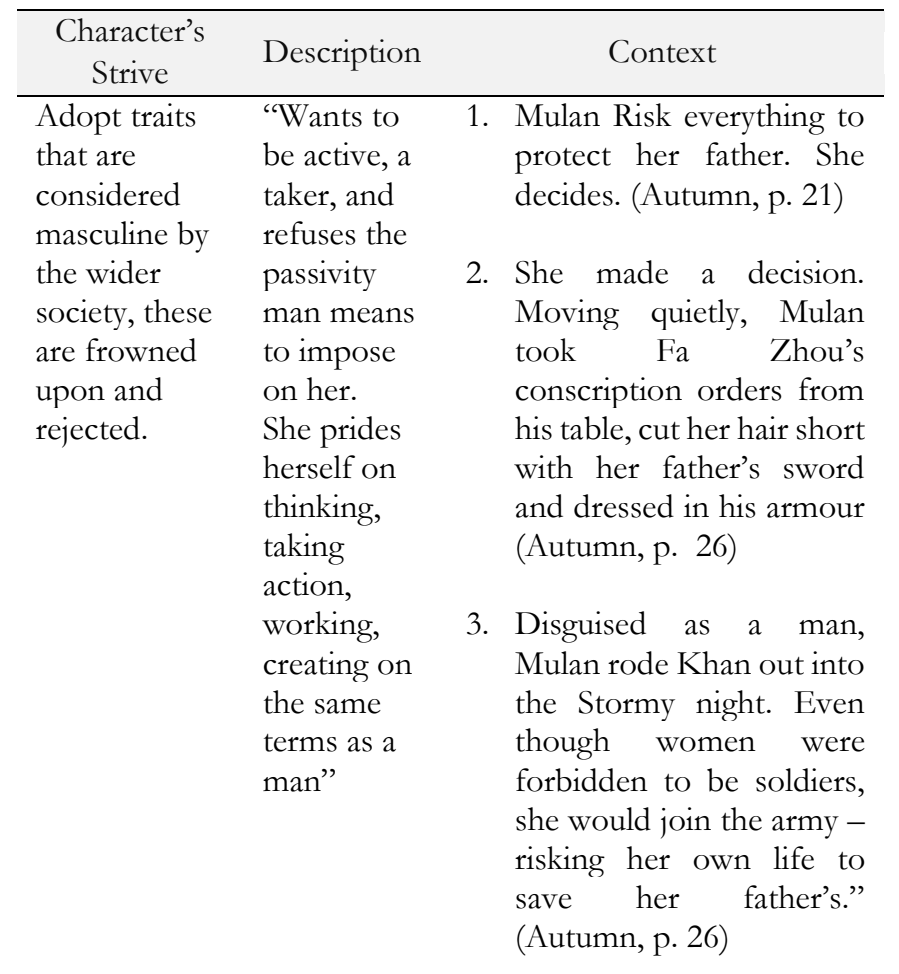

4. A sudden idea spurred Mulan into action. She grabbed the cannon and raced towards Shan-Yu. ... she reached down and pulled Shang up behind her ... (Autumn, p. 32)

5. Thinking fast, Mulan disguised Yao, Chien-Po and Ling as women and led them to the palace.... Their disguises worked! (Autumn, p.35)

6. The Emperor approached Mulan. 'I've heard a great deal about you' he said sternly. "You stole your

father's armour,
impersonated a soldier,
dishonoured the Chinese
Army, destroyed my
palace and ... save us all”'
then, to everyone's
amazement, the Emperor
bowed to Mulan. ...”
(Autumn, p. 37)
7. The greatest gift and
honour is having you for
daughter' Fa Zhou said ...
Mulan had become a hero
and a leader, bringing
honour to her family in
her own way. ...
(Autumn, p. 38)

Table 5: The Story of Mulan in Mulan p. 21-38

To break the traditional gender roles, Disney characters appropriating masculine attributes and roles. In the selected Disney renaissance, an interesting one is Mulan, who adopts such masculine attributes outright and male identity to take the place of her ailing father in the Chinese military and claiming her equality to get self-actualization. Mulan is headstrong and not the 'quiet and demure, graceful, and delicate' woman that her family and maledominated Chinese society want her to be. In this category, the data contained in the story of Mulan. Mulan independently risking herself to be active and taking action to save her father, she prides herself to be what she decides to create on the same terms as a man and break the traditional gender roles defined by society. Mulan independently risking herself to be active and taking action to save her father, she prides herself to be what she decides to create on the same terms as a man and break the traditional gender roles defined by society.

\section{CONCLUSION}

From the result of data analysis of the female representation depicted and claimed their equality as a woman in Disney Renaissance stories, the writer found sixth parts of data by using gender equality approach analysis and second-wave feminism theory from Simone de Beauvoir. In the part of female representation depicted in the stories, the writer found Princess Ariel and Pocahontas as the women 
who are rebelling, wise, and adventurous. Belle, Princess Jasmine, and Princess Ariel as the women who are confident, intelligent, and repellent of domestication. Furthermore, Mulan, Pocahontas, and Belle as the women who are Masculine, loyal, and ambitious.

Furthermore, by analyzing the character's struggles in claiming their equality as a woman in their society in the Disney Renaissance stories, the writer found the part of female representations those who exceed patriarchal expectations through independence and persistence through hard work and persistence, achieve self-actualization. Then, rejecting domestication and applying emancipation are realized through independence. Emancipating themselves from their domesticated role in society is aimed to get their self-actualization -not merely following their feminine tradition. Lastly, the writer found the Disney characters appropriating masculine attributes and roles to break the traditional gender roles.

\section{REFERENCES}

[1] Ramrao, D. T. (2016). Film and Literature: An Overview. International Journal of Multidisciplinary Research, 150.

[2] May, J. P. (1981). Walt Disney's Interpretation of Children's Literature. Language Arts, Vol. 58, No. 4, Children's Literature, 464.

[3] Tonn, T. (2008). Disney's Influence on Females Perception of Gender and Love. A Research Paper, 5.

[4] Beal, C. (1994). Boys and girls: The development of gender roles. New York: McGraw-Hill.

[5] Lant, J. (2018, SEPTEMBER 7). A Briefish History of The Disney Renaissance. Retrieved from theopinionarcade:

https://theopinionarcade.com/a-briefishhistory-of-the-disney-renaissance/

[6] Abler, A. (2005). The Moral of the Story (Society and Culture, Ethics and Morality). Retrieved from VISION: https://www.vision.org/the-moral-ofthe-story-fairy-tales-mirror-society-981
[7] Stover, C. (2013). Damsels and Heroines: The Conundrum of the Post-Feminist Disney Princess. A Journal of Transdisciplinary Writing and Research h from Claremont Graduate University: Vol. 2: Iss. 1, Article 29., 4.

[8] Lindgren, A. (2020). Animated Stereotypes - An Analysis of Disney's Contemporary Portrayals of Race and Ethnicity. Master Thesis, 90.

[9] Garabedian, J. (2014). Animating Gender Roles: How Disney is Redefining the Modern Princess. James Madison Undergraduate Research Journal, 2(1), 22-25.

[10]Barber, M. (2015). Disney's Female Gender Roles: The Change of Modern Culture. Honors Thesis.

[11]Walsh, K. T. (2010, March 12). The 1960s: A Decade of Change for Women. Retrieved from U.S News: https://www.usnews.com/news/articles/2010/ 03/12/the-1960s-a-decade-of-change-forwomen

[12]CIDA. (1999). CID A's policy on gender equality. Hull, Quebec: Canadian International Development Agency.

[13]Moran, M. (1989). 1930s, America-Feminist Void? The Status of the Equal Rights Movement during the Great Depression. The Department of History as the Outstanding Paper for the 1988-89 academic year.

[14]Tongs, R. (2009). Feminist Thought Third Edition. Boulder: Westview Press.

[15]Drucker, S. A. (2018, April 27). Betty Friedan: The Three Waves of Feminism. Retrieved from Ohio Humanities (Blog and News): http://www.ohiohumanities.org/betty-friedanthe-three-waves-offeminism/\#: : :text $=$ The $\% 20$ second $\% 20$ wave $\%$ 2C $\% 20$ at $\% 20$ its, to $\% 2 \mathrm{C} \% 20$ second $\% 2$ Dwave $\% 2$ 0feminism.\&text $=$ This $\% 20$ causes $\% 20$ women $\%$ 20to $\% 20$ lose, in $\% 20$ that $\% 20$ of $\% 20$ their $\% 20$ fami ly.

[16] Anand, T. (2018, April 25). A Brief Summary Of The First Wave Of Feminism. Retrieved from FII (Feminism

in

India): 
https://feminisminindia.com/2018/04/25/sum mary-second-wave-of-feminism/

[17]Kristen Schiele, L. L. (2020). Marketing feminism in youth media: A study of Disney and Pixar animation. journals elsevier, 2 .

[18]Salden, M. (2019). 'Disney's Damsels' A representation of femininity in Disney's animated movies Snow White, Mulan, and Brave. Master Thesis Creative Industries Radboud University Nijmegen, 6.

[19]Beck, K. A. (2018). Beyond the Independent Woman: A Reading of Simone de Beauvoir's When Things of the Spirit Come First with The Second Sex. School of Historical and Philosophical Inquiry, 18.

[20]Walters, M. (2005). Feminism: A Very Short Introduction. United States: Oxford University Press Inc., New York.

[21]Berg, B. L. (2007). Qualitative Research Methods for the Social Sciences $(6$ th ed). California State University, Long Beach: Pearson.

[22]Tur, A. P. A. \& Sari, F.A. (2019). Reshaping the society face through the culture of horror told in Shirley Jackson's the lottery. Notion: Journal of Linguistics, Literature, and Culture, Vol. 1 (1), p. 1-7. http://www.journal2.uad.ac.id/index.php/notio n/article/download/709/377

[23]Tur, A. P. A. \& Putri, S. A. (2020). Codes of teenage characters and mama in their talks portraying the sociolinguistic features. Leksika: Jurnal Bahasa, Sastra dan Pengajarannya Vol 14 (2), p. 46-51. http://www.jurnalnasional.ump.ac.id/index.php LLEKSIKA/article/viewFile/7638/3318

[24]Sawyer, N. (2003). Feminist Outlooks at Disney Princess‘s. James Madison University, 3.

[25]FitzGerald, C. (2019, August 03). A Defence of the Princesses of Disney's Renaissance. Retrieved from medium.com: https://medium.com/ 